\title{
Evaluation and Efficacy of Trichoderma spp., Botanicals Extract and Chitosan against Fusarium oxysporum f. sp. lycopersici under In vivo (Greenhouse)
}

\author{
Shivam Maurya ${ }^{1 *}$, Dinesh Rai ${ }^{1}$, Saurabh Dubey ${ }^{1}$, Mukul Kumar ${ }^{1}$ and Poonam kumari ${ }^{2}$ \\ ${ }^{1}$ Department of Plant Pathology at Dr. Rajendra Prasad Central Agriculture University, \\ Pusa, Samastipur, Bihar-848125, India \\ ${ }^{2}$ Department of Plant Pathology at Sri Karan Narendra Agriculture University Jobner, \\ Jaipu, r Rajasthan, India \\ *Corresponding author
}

\section{A B S T R A C T}

\begin{tabular}{|l|}
\hline Ke y w o r d s \\
$\begin{array}{l}\text { Trichoderma } \\
\text { asperellum, } \\
\text { Chitosan, Fusarium } \\
\text { oxysporum f. sp. } \\
\text { lycopersici, } \\
\text { Botanical extract }\end{array}$ \\
\hline Article Info \\
\hline $\begin{array}{l}\text { Accepted: } \\
\text { 18 January } 2020 \\
\text { Available Online: } \\
\text { 10 February } 2020\end{array}$ \\
\hline
\end{tabular}

\section{Introduction}

Tomato (Solanum lycopersicum L.) is one of the most popular and widely grown vegetable crops in the world and universally treated as "Protective food" (Thamburaj and Singh, 2013). India ranks second in the area as well as in production of Tomato. The major tomato growing countries are China (30.7\%), India $(11.5 \%)$, USA $(8.1 \%)$, Turkey $(7.0 \%)$ and Egypt $(5.3 \%)$. In India, it is being grown in about 7.67 lakh hectares with an annual production of 163.85lakh metric tonnes. (Horticultural Statistics at a Glance 2017). Many diseases and disorders can affect tomatoes during the growing season proving to be a major limiting factor for tomato production. These diseases can be classified into two groups. The first group includes those caused by non-infectious physical or chemical factors, such as adverse environmental factors, nutritional or 
physiological disorders and herbicide injury. These disorders occur primarily in field grown rather than greenhouse-grown tomatoes viz. Blossom end rot, Fruit cracking, Cat faced fruit, Sunscald, Blotchy ripening, Physiological leaf roll, Herbicide injury and failure to set fruit etc. The second are those diseases which are caused by infectious microorganisms that include fungi, bacteria, viruses and nematodes. These diseases are contagious and can spread from plant to plant in a field, often very rapidly when environmental conditions are favorable. Major plant diseases which cause economic damage include wilt, damping-off, early blight, late blight, Septoria leaf spot, leaf curl, tobacco mosaic, root-knot, many fruit rots etc.

Among these wilt caused by Fusarium oxysporum f. sp. lycopersici (Sacc.) is most devastating disease, resulting in 10-50 per cent crop loss around the world (Lukyanenko, 1991). The pathogen, F. oxysporum f. sp. lycopersici is soil-borne and persists for longer periods in the soil. Most of the popular tomato varieties grown in our country are reported to be susceptible to Fusarium wilt (Chauhan, 1988 and Kapoor, 1988). Incident of vascular wilt of tomato, alone causes 30$40 \%$ yield loss and in India, under adverse weather conditions, the losses may reach as high as $80 \%$ (Nirmaladevi et al., 2016). The disease is systemic in nature and the pathogen may infect plants at any growth stage. Wilting at early stages is responsible for greater yield loss than that at later stages. The pathogen is soil as well as seed-borne in nature and causes vascular wilts by infecting plants through the roots and growing internally through the cortex to the stele (Bowers and Locke, 2000) thereby causing xylem browning or blackening. The pathogen can survive in the soil up to 6 years even in the absence of a host plant. The expression of symptoms is rapid at high temperature and is influenced by the soil environment.
In recent years, the increasing use of potentially hazardous fungicides and insecticides in agriculture has been the subject of growing concern for both environmentalists and public health authorities. The possibilities of controlling plant diseases by the integration of several methods have been the subject of extensive research. An integrated control which denotes the rational use of all available control measures will have to be considered, especially with a crop like tomato which is infected simultaneously by various types of pathogens. It does offer the possibility of making up for the deficiencies of any single method. This disease is rather difficult to control with fungicides alone due to its soilborne nature. It is now widely recognized that several microorganisms have been successfully used for the control of tomato wilt (Padmodaya and Reddy, 1998).

\section{Materials and Methods}

The experiment was conducted under greenhouse conditions in plastic pots $(2 \mathrm{~kg}$ capacity) filled with sterilized well pulverized sandy-loam soil mixed with vermicompost (200g /pot). Each pot was inoculated with culture of Fusarium oxysporum f. sp. lycopersici@10g/ pot before 10 days of transplanting. The tomato seeds (Jagannath tomato -3) obtained from the Vegetable Department, RPCAU, for the study. Twentyone days old tomato seedlings were transplanted in each pots (5No.) after one week of pathogen inoculation while without any treatment served as check. Watering of pots was done when required to maintain optimum level of moisture. The temperature of Greenhouse chamber was maintained at $25^{\circ} \mathrm{C}$. The experiment was laid out in a completely randomized design with three replications. The following treatments were imposed. 


\section{Experimental finding}

During the investigation seedling treatment alone and seedling treatment followed by foliar spray of treatments was significantly superior over inoculated control in reducing per cent disease index (Table 10). Maximum reduction in per cent disease index was observed in treatment T4 (Seedling treatment with Trichoderma asperellum @ 5g/lit + Chitosan @ 0.1\% followed by its foliar spray) in which 44.66 per cent PDI recorded and was at par with T5 (Seedling treatment with Th-8 @ 5g/lit + Chitosan @ $0.1 \%$ followed by its foliar spray) in which 49.37 per cent PDI observed.Whereas maximum per cent disease index was recorded in inoculated control $(71.35 \%)$. However, treatment T5 was at par with T3, T1 and T2 and PDI was recorded $51.42 \%, 52.95$ and $53.09 \%$ respectively. (Fig1, Plate 1 and table 2)

\section{Results and Discussion}

Biological control, in integration with fungicidal treatment was found to be a more reliable approach to manage soil-borne plant pathogens (Mukhopadhyay, 1987). As the management of soil-borne diseases is not possible through only one approach, in recent years' effort was made to reduce environmental effects and rationalize the use of pesticides and manage diseases more effectively which led to the emergence of the new discipline called Integrated Disease Management (IDM). For sustainable crop production, the components involved should be ecofriendly, so that beneficial organism would be safe and IDM practices would go a long way helping stabilized crop production. Keeping in view the importance of integrated disease management, a study was undertaken to control Fusarium oxysporum f. sp. lycopersici in tomato by combining effective antagonist Trichoderma harzianum (Th 8 isolate) and Chitosan in pot culture. Plant extracts were also effective in minimizing the plant disease severity.

In course of present study seedling root dipping, treatment T5 (Seedling treatment with Trichoderma harzianum @ 5g/lit + Chitosan @ 0.1\% followed by its foliar spray) was found effective (PDI= 49.37\%) in controlling the Fusarium wilt of tomato and was at par with University strain. However minimum per cent disease index $(32.39 \%)$ was observed in treatment T10 Seedling treatment with Carbendazim @ 0.1\%.

Table.1 Treatments details

\begin{tabular}{|c|c|c|}
\hline SI. No & Treatment & Description \\
\hline 1. & $\mathrm{~T}_{1}$ & Seedling treatment with Chitosan @ 0.1\% \\
\hline 2. & $\mathrm{~T}_{2}$ & Seedling treatment with Garlic @ 10\% \\
\hline 3. & $\mathrm{~T}_{3}$ & Seedling treatment with Garlic @ 10\% followed by its foliar spray \\
\hline 4. & $\mathrm{~T}_{4}$ & $\begin{array}{l}\text { Seedling treatment with Trichoderma asperellum }(5 \mathrm{~g} / \mathrm{lit})+\text { Chitosan }(0.1 \%) \text { followed } \\
\text { by its foliar spray }\end{array}$ \\
\hline 5. & $T_{5}$ & Seedling treatment with Th8 $(5 \mathrm{~g} / \mathrm{lit})+$ Chitosan $(0.1 \%)$ followed by its foliar spray \\
\hline 6. & $\mathrm{~T}_{6}$ & Seedling treatment with Yam beam seed extract @30\% \\
\hline 7. & $\mathrm{~T}_{7}$ & Seedling treatment with Yam beam seed extract @30\% followed by its foliar spray \\
\hline 8. & $\mathrm{~T}_{8}$ & Seedling treatment with Elephant foot yam @ 30\% \\
\hline 9. & $\mathrm{~T}_{9}$ & Seedling treatment with Elephant foot yam @30\% followed by its foliar spray \\
\hline 10. & $\mathrm{~T}_{10}$ & Seedling treatment with Carbendazim @ 0.1\% \\
\hline 11. & $\mathrm{~T}_{11}$ & Inoculated Control \\
\hline
\end{tabular}


Table.2 Evaluation \& efficacy of Trichoderma spp., botanicals extract and chitosan against Fusarium oxysporum f. sp. lycopersici in vivo (greenhouse)

\begin{tabular}{|c|c|c|c|}
\hline No. & Treatments & Description & PDI (\%) \\
\hline 1. & $\mathrm{~T} 1$ & Seedling treatment with Chitosan@0.1\% & $52.95(46.67)$ \\
\hline 2. & $\mathrm{~T} 2$ & Seedling treatment with Garlic @ 10\% & $53.09(46.75)$ \\
\hline 3 & $\mathrm{~T} 3$ & $\begin{array}{l}\text { Seedling treatment with Garlic @ } 10 \% \\
\text { followed by its foliar spray }\end{array}$ & $51.42(45.79)$ \\
\hline 4 & $\mathrm{~T} 4$ & $\begin{array}{l}\text { Seedling treatment with Trichoderma } \\
\text { asperellum }(5 \mathrm{~g} / \mathrm{lit})+\text { Chitosan }(0.1 \%) \text { followed } \\
\text { by its foliar spray }\end{array}$ & $44.66(41.91)$ \\
\hline 5 & T5 & $\begin{array}{l}\text { Seedling treatment with Th- } 8 \text { ( } 5 \mathrm{~g} / \mathrm{lit})+ \\
\text { Chitosan }(0.1 \%) \text { followed by its foliar spray }\end{array}$ & $49.37(44.62)$ \\
\hline 6 & T6 & $\begin{array}{l}\text { Seedling treatment with Yam beam seed } \\
\text { extract @ } 30 \%\end{array}$ & $56.28(48.59)$ \\
\hline 7 & $\mathrm{~T} 7$ & $\begin{array}{l}\text { Seedling treatment with Yam beam seed } \\
\text { extract @30\% followed by its foliar spray }\end{array}$ & $57.09(49.05)$ \\
\hline 8 & T8 & $\begin{array}{l}\text { Seedling treatment with Elephant foot yam @ } \\
30 \%\end{array}$ & $62.70(52.35$ \\
\hline 9 & T9 & $\begin{array}{l}\text { Seedling treatment with Elephant foot yam @ } \\
30 \% \text { followed by its foliar spray }\end{array}$ & $58.33(49.78)$ \\
\hline 10 & T10 & Seedling treatment with Carbendazim @ $0.1 \%$ & $32.39(34.66)$ \\
\hline \multirow[t]{3}{*}{11} & $\mathrm{~T} 11$ & Inoculated Control & $71.35(57.63)$ \\
\hline & C.D. $(P<0.5)$ & & $6.02(3.50)$ \\
\hline & CV & & $6.69(4.37)$ \\
\hline
\end{tabular}

* Mean of three replication

Fig.1 Efficacy of Trichoderma isolates, fungicide, botanicals extract and chitosan for management of tomato wilt in vivo (greenhouse)

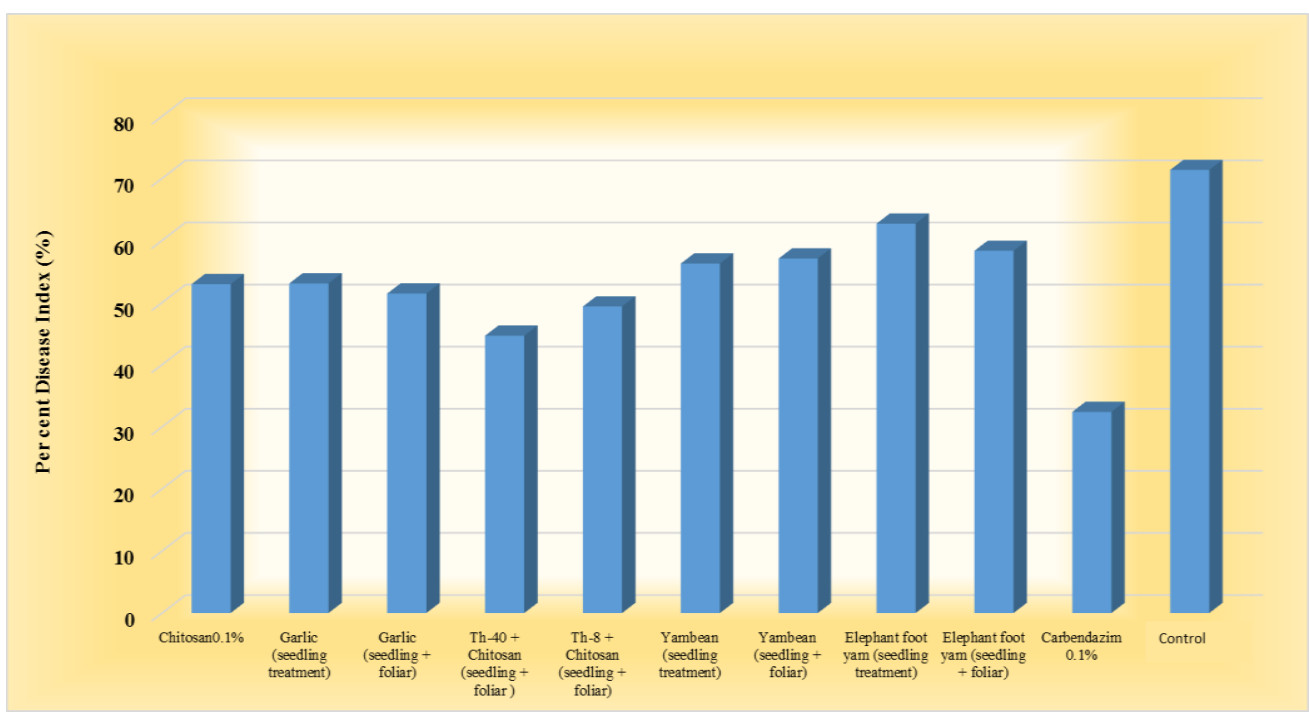


Plate.1 Management of Fusarium oxysporum f. sp. lycopersici in pot condition

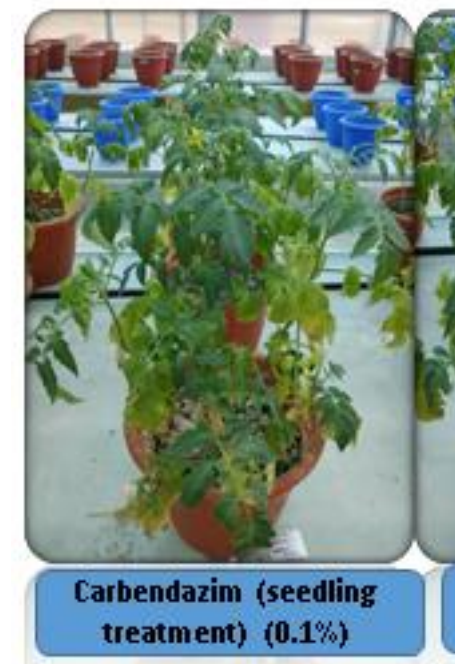

Treatment

no.

$\mathrm{T}_{1} \quad$ : Seedling treatment with Chitosan @ $0.1 \%$

$\mathrm{T}_{2} \quad$ : Seedling treatment with Garlic @ 10\%

$\mathrm{T}_{3} \quad$ : Seedling treatment with Garlic @ 10\% followed by its foliar spray

$\mathrm{T}_{4} \quad$ : Seedling treatment with Trichoderma asperellum $(5 \mathrm{~g} / \mathrm{lit})+$ Chitosan $(0.1 \%)$ followed by its foliar spray

$\mathrm{T}_{5} \quad$ : Seedling treatment with $\mathrm{Th}-8(5 \mathrm{~g} / \mathrm{lit})+$ Chitosan $(0.1 \%)$ followed by its foliar spray

$\mathrm{T}_{6} \quad$ : Seedling treatment with Yam beam seed extract @30\%

$\mathrm{T}_{7} \quad$ : Seedling treatment with Yam beam seed extract @30\% followed by its foliar spray

: Seedling treatment with Elephant foot yam @ 30\%

T8 $\quad$ : Seedling treatment with Elephant foot yam @ 30\% followed by its foliar spray

$\mathrm{T}_{10} \quad$ : Seedling treatment with Carbendazim @ $0.1 \%$

$\mathrm{T}_{11} \quad$ : Inoculated Control
More or less similar results were obtained by Christopher et al., (2010) who evaluated various isolates of $T$. virens under in vitro and green house condition for efficacy in suppressing incidence of Fusarium wilt disease and promoting plant growth in tomato. Margaret et al., (2011). studied the ability of isolate of Trichoderma harzianum (P52) and arbuscular mycorrhizal fungi (AMF) in enhancing growth and control of a wilt pathogen caused by Fusarium oxysporum f. sp. lycopersici. Barari (2016) evaluated 28 native Trichoderma spp. against tomato wilt in vitro and in vivo. Trichoderma harzianum, isolate $\mathrm{N}-8$, was most effective in reducing radial mycelial growth of the pathogen (by 68.22\%) and least disease incidence (by $14.75 \%)$.

In conclusion among 11 treatments imposed in pot experiment, treatment T10 (Seedling treatment with Carbendazim @ 0.1\%) was found to be superior as it recorded least per cent disease index 32.39 per cent. However, among the ecofriendly treatments, treatment T4 (Seedling treatment with Trichoderma asperellum @ 5g/lit + Chitosan @ 0.1\% followed by its foliar spray) in which 44.66 per cent PDI recorded and was at par with T5 (Seedling treatment with Th-8 @ 5g/lit + 
Chitosan @ $0.1 \%$ followed by its foliar spray) in which 49.37 per cent PDI observed.

\section{References}

Barari, H. (2016).Biocontrol of tomato Fusarium wilt by Trichoderma species under in vitro and in vivo conditions. In. Moldova. 165 (1): 91-98.

Bowers, J. H. and Locke, J. C. (2000) Effect of botanical extracts on the population density of Fusarium oxysporum in soil and control of Fusarium wilt in the greenhouse. Plant Dis. 84: 300-305.

Chauhan, M. S. (1988) Reaction of varieties / lines of tomato to wilt. Indian Journal of Mycology and Plant Pathology. 18:72-73.

Christopher, D. J., Raj, T. S., Rani, S. U. and Kumar, R. U.(2010). Role of defense enzymes activity in tomato as induced by Trichoderma virens against Fusarium wilt caused by Fusarium oxysporum f sp. lycopersici. Journal of Biopesticides. 3(1): 158 - 162

Kapoor, I. J.(1988). Fungi involved in tomato wilt syndrome in Delhi, Maharashtra and Tamil Nadu. Indian Phytopathology. 41(2): 208-213.

Lukyanenko, A. N. (1991). Disease resistance in tomato (Ed. Kalloo,G.) monographs on theoretical and applied genetics.14. Springer Verlag, Berlin Heidelberg. 99-119.

Margaret, W. M., Ethel, O. M., Sheila, A. O., and Joyce, M. J. (2011). Inoculation of tomato seedlings with Trichoderma harzianum and Arbuscular Mycorrhizal Fungi and their effect on growth and control of wilt in tomato seedlings. Braz. J. Microbiol. 42(2): 508-513

Nirmaladevi, D., Venkataramana, M., Srivastava, R. K., Uppalapati, S. R., Gupta, V. K., Yli-Mattila, T. and Chandra, N. S. (2016). Molecular phylogeny, pathogenicity and toxigenicity of Fusarium oxysporum $\mathrm{f}$. sp. lycopersici. Sci. Rep. 6: 21367.

Padmodaya, B. and Reddy, H. (1998). RScreening of antagonists against Fusarium oxysporum f. sp. lycopercisi causing seedling disease and wilt in tomato. Indian J. Mycol. Pl. Pathol. . 28:339-341

Thamburaj, S. and Singh, N. (2013). Text book of Vegetables, Tubercrops and Spices, Indian Council of Agriculture Research Publications, New Delhi, p. 309.

\section{How to cite this article:}

Shivam Maurya, Dinesh Rai, Saurabh Dubey, Mukul Kumar and Poonam kumari. 2020. Evaluation and Efficacy of Trichoderma spp., Botanicals Extract and Chitosan against Fusarium oxysporum f. sp. lycopersici under In vivo (Greenhouse). Int.J.Curr.Microbiol.App.Sci. 9(02): 2603-2608. doi: https://doi.org/10.20546/ijcmas.2020.902.297 